\title{
Erratum to: development and psychometric testing of a new instrument to measure factors influencing women's breast cancer prevention behaviors (ASSISTS)
}

Maryam Khazaee-Pool ${ }^{1 *}$, Fereshteh Majlessi ${ }^{2 *}$, Ali Montazeri ${ }^{3}$, Tahereh Pashaei ${ }^{4,5}$, Ali Gholami $^{6,7}$ and Koen Ponnet ${ }^{8,9,10}$

\section{Erratum}

Following publication of the original article [1] it was brought to our attention that the third author's family name had been incorrectly spelt. Please note that the third author's family name is Montazeri and not Montazaeri.

This has now been updated on the BioMed Central website.

\begin{abstract}
Author details
'Department of Health Education and Promotion, School of Health, Zanjan University of Medical Sciences, Parvin Etesami Street, P.O. Box: 451578-6349, Zanjan, Iran. ${ }^{2}$ Department of Health Education and Promotion, School of Health, Tehran University of Medical Sciences, P.O. Box 15875-6951, Tehran, Iran. ${ }^{3}$ Mental Health Research Group, Health Metrics Research Center, Institute for Health Sciences Research, ACECR, Tehran, Iran. ${ }^{4}$ Social Determinants of Health Research Center, Kurdistan University of Medical Sciences, Sanandaj, Iran. ${ }^{5}$ Department of public health, School of Health, Kurdistan University of Medical Sciences, Sanandaj, Iran. ${ }^{6}$ Department of Public Health, Neyshabur University of Medical Sciences, Neyshabur, Iran. ${ }^{7}$ Department of Epidemiology, School of Public Health, Iran University of Medical Sciences, Tehran, Iran. ${ }^{8}$ Department of Communication Studies and Sociology, University of Antwerp, Antwerp, Belgium. ${ }^{9}$ Higher Institute for Family Sciences, Odisee, Brussels, Belgium. ${ }^{10}$ Antwerp Maritime Academy, Antwerp, Belgium.
\end{abstract}

Received: 1 August 2016 Accepted: 1 August 2016

Published online: 10 August 2016

\section{Reference}

1. Khazaee-Pool, et al. Development and psychometric testing of a new instrument to measure factors influencing women's breast cancer prevention behaviors (ASSISTS). BMC Womens Health. 2016;16:40.

\footnotetext{
*Correspondence: khazaie_m@yahoo.com; khazaee.m@zums.ac.ir; dr_f_majlessi@yahoo.com

'Department of Health Education and Promotion, School of Health, Zanjan University of Medical Sciences, Parvin Etesami Street, P.O. Box: 451578-6349, Zanjan, Iran

${ }^{2}$ Department of Health Education and Promotion, School of Health, Tehran University of Medical Sciences, P.O. Box 15875-6951, Tehran, Iran
}

\footnotetext{
Submit your next manuscript to BioMed Central and we will help you at every step:

- We accept pre-submission inquiries

- Our selector tool helps you to find the most relevant journal

- We provide round the clock customer support

- Convenient online submission

- Thorough peer review

- Inclusion in PubMed and all major indexing services

- Maximum visibility for your research
}

Submit your manuscript at www.biomedcentral.com/submit (c) 2016 The Author(s). Open Access This article is distributed under the terms of the Creative Commons Attribution 4.0 International License (http://creativecommons.org/licenses/by/4.0/), which permits unrestricted use, distribution, and reproduction in any medium, provided you give appropriate credit to the original author(s) and the source, provide a link to the Creative Commons license, and indicate if changes were made. The Creative Commons Public Domain Dedication waiver (http://creativecommons.org/publicdomain/zero/1.0/) applies to the data made available in this article, unless otherwise stated. 